\title{
Oregano essential oil supplementation improves productive performance, oxidative stability, and lipid parameters in turkeys
}

\author{
Gilmar Mendoza-Ordoñez ${ }^{1, *}(\mathbb{D})$; Luis Caceda-Gallardo ${ }^{1}\left(\mathbb{D}\right.$; Bruno Loyaga-Cortéz ${ }^{1}$ (D); \\ Roberto Ybañez-Julca ${ }^{2}{ }^{(\mathbb{D}}$; Diego Gonzales-Nonato ${ }^{2}{ }^{(\mathbb{D})}$; Daniel Asunción-Alvarez ${ }^{2}$ (D) \\ 1 Departamento de Agronomía y Zootecnia, Facultad de Ciencias Agropecuarias, Universidad Nacional de Trujillo. Av. \\ Juan Pablo II s/n, Ciudad Universitaria, Trujillo, Peru. \\ 2 Departamento de Farmacología, Facultad de Farmacia y Bioquímica, Universidad Nacional de Trujillo. Av. Juan Pablo \\ // s/n, Ciudad Universitaria, Trujillo, Peru.
}

Received January 30, 2020. Accepted May 15, 2020.

\begin{abstract}
The present study evaluated the effect of supplementation with oregano essential oil (OEO) on the productive parameters, oxidative stability, and lipid parameters of turkey meat. Eighty 1-d-old male turkeys were randomly distributed into four treatment groups and fed the following diets for 105 days: control diet without any supplementation or supplementation with $300 \mathrm{mg} / \mathrm{kg}$ lincomycin and spectinomycin, $100 \mathrm{mg} / \mathrm{kg}$ OEO, or $200 \mathrm{mg} / \mathrm{kg}$ OEO. Supplementation with $200 \mathrm{mg} / \mathrm{kg}$ OEO obtained the best bodyweight, average daily gain, feed conversion, and the lowest feed intake concerning the other diets $(p<0.001)$, while $100 \mathrm{mg} / \mathrm{kg}$ OEO had the best oxidative stability $(p<0.001)$. Though OEO had no hypocholesterolemic effect, $200 \mathrm{mg} / \mathrm{kg}$ OEO produced the lowest concentration of triglycerides in the blood $(p<0.05)$. In conclusion, OEO supplementation improves productive parameters and increases oxidative stability in turkeys. Therefore, OEO has the potential to act as a growth promoter replacing antibiotics.
\end{abstract}

Keywords: Oregano essential oil; productive parameters; oxidative stability; lipidic profile; turkey.

\section{Introduction}

In poultry farming, the use of antibiotics is intended to prevent diseases and stimulate growth. Therefore, they are typically provided at subtherapeutic doses in the feed to increase production. However, their misuse/overuse contributes to antibiotic resistance, a significant worldwide public health problem (Ardoino et al., 2017; GaticaEguiguren and Rojas, 2018). With the increased interest in the nutritional properties of meat, consumption has increased considerably, especially in poultry. Compared to other types of meat, turkey is rich in protein, vitamins, and minerals and low in fat. Importantly, the growth conditions of farm birds are a key factor influencing both the quantity and quality of meat produced (Vaitukaityte et al., 2013). Besides, muscle from turkeys is more sensitive to lipid oxidation during postmortem storage compared with that of chicken and duck (Perez et al., 2019).

Compared to red meat, the meat of farmed birds is more susceptible to lipid oxidation because it has less stable fatty acids (Adeyemi and Olorunsanya et al., 2012). Excess oxidative stress leads to an overall imbalance in redox homeostasis (tuczaj et al., 2017) and lipid peroxidation, which alters the biological properties of membranes and generates cytotoxic aldehydes, such as malondialdehyde (MDA), who present negative impacts, by causing additional damages to biomolecules (proteins and DNA) and the off-flavors associated to edible fats rancidification (Félix et al., 2019). For this reason, this aldehyde has great importance in meat because at low amounts it produces rancid aromas, and it is the major

Cite this article:

Mendoza-Ordoñez, G.; Caceda-Gallardo, L.; Loyaga-Cortéz, B.; Ybañez-Julca, R.; Gonzales-Nonato, D.; Asunción-Alvarez,

D. 2020. Oregano essential oil supplementation improves productive performance, oxidative stability, and lipid parameters in turkeys. Scientia Agropecuaria 11(2): 187-193. 
marker of lipid oxidation (Domínguez et al., 2020). Furthermore, the transport of animals and environmental conditions have also been shown to increase oxidative stress in the meat (Hcini et al., 2018). Hence, antimicrobials are typically used as growth promoters for farmed birds and other animals (Xiong et al. 2018).

Concerns about antibiotic-resistant microorganisms, coupled with the growing demand for high-quality animal protein free of antibiotics and harmful compounds, have initiated a demand for new alternative functional feeding strategies (Kiarie et al., 2016). Since ancient times, essential oils have been used due to their beneficial effects on humans and animals. They have been widely used for antibacterial, antiviral, fungicidal, anticancer, and cytotoxic activities, among others (Stevanović et al., 2018). Oregano essential oil (OEO) has been recognized for its antimicrobial and antioxidant properties. OEO has also been shown to be more effective against grampositive bacteria than gram-negative, the main compounds in OEO responsible for these properties are carvacrol and thymol, both of which are present regardless of geographical area, species, or harvest season (Rodriguez-Garcia et al., 2016).

The nutrition of farmed turkeys is critical because their bodily and digestive functions are fast, thereby accelerating its growth. Therefore, the turkey diet requires effective growth promoters that not only control the bacterial load of the digestive tract but also contribute to the quality of the meat. The present study evaluated the effect of supplementation with oregano (Origanum vulgare) essential oil (OEO) on the productive parameters, oxidative stability, and lipid parameters of turkey meat.

\section{Materials and methods}

\subsection{Animals, diets, and experimental design}

The turkeys (Meleagris gallopavo) were provided by a local farm located in Santo Domingo (Laredo, La Libertad, Peru). Dietary and productive parameter analyses were carried out in the Laboratorio de Nutrición Animal of the Facultad de Ciencias Agropecuarias of the Universidad Nacional de Trujillo (Trujillo, La Libertad, Peru), while oxidative stability and lipid profile analyses were done in the Laboratory of Pharmacology of the Faculty of Pharmacy and Biochemistry. This study was approved by an animal ethics committee and adhered to the code of ethics for research at the Universidad Nacional de Trujillo.

Eighty 1-d-old male turkeys were equally distributed into four dietary treatment groups ( $n=20$ per group), and each group was housed in one pen under conventional conditions with access to food and water ad libitum and 12-h photoperiod. The treatment groups were as follows: control diet, standard feed without supplements; L\&S diet, standard feed supplemented with $\mathbf{3 0 0}$ $\mathrm{mg} / \mathrm{kg}$ lincomycin and spectinomycin; OEO100, standard feed supplemented with $100 \mathrm{mg} / \mathrm{kg} \mathrm{OEO;} \mathrm{OEO200,} \mathrm{standard} \mathrm{feed}$ supplemented with $200 \mathrm{mg} / \mathrm{kg}$ OEO.

Table 1

Dietary contents supplied from day 0 to 105

\begin{tabular}{|c|c|c|c|c|c|}
\hline \multirow[b]{2}{*}{ Ingredients (kg) } & \multicolumn{5}{|c|}{ Diet at different growth stages } \\
\hline & $\begin{array}{l}\text { Starter } 1 \\
(0-28 d)\end{array}$ & $\begin{array}{c}\text { Starter } 2 \\
(29-42 \text { d) }\end{array}$ & $\begin{array}{c}\text { Grower } 1 \\
(43-56 \text { d) }\end{array}$ & $\begin{array}{c}\text { Grower } 2 \\
(57-77 \text { d) }\end{array}$ & $\begin{array}{c}\text { Grower } 3 \\
(78-105 \text { d) }\end{array}$ \\
\hline Corn grain & 29.5 & 37.5 & 42.5 & 46 & 52.5 \\
\hline Soybean meal & 34.5 & 28.5 & 18.5 & 12.5 & 12 \\
\hline Soy pressed cake & 22.5 & 23 & 25 & 27 & 27.5 \\
\hline Rice husk powder & 7.7 & 4.4 & 8 & 10.4 & 5 \\
\hline Calcium carbonate & 0.5 & 0.75 & 0.6 & 0.66 & 0.57 \\
\hline Dicalcium phosphate & 2.7 & 2.6 & 2.3 & 2.3 & 1.68 \\
\hline Salt & 0.16 & 0.24 & 0.15 & 0.21 & 0.21 \\
\hline Methionine & 0.27 & 0.3 & 0.3 & 0.29 & 0.28 \\
\hline Lysine & 0.03 & 0.1 & 0.08 & 0.1 & 0.1 \\
\hline Sodium bicarbonate & 0 & 0.03 & 0 & 0 & 0 \\
\hline Choline chloride & 0.06 & 0.04 & 0.04 & 0.4 & 0.03 \\
\hline Vitamins and minerals* & 0.1 & 0.1 & 0.1 & 0.1 & 0.1 \\
\hline Dairy-based concentrate & 2 & 2.5 & 2.5 & 0.1 & 0.1 \\
\hline \multicolumn{6}{|l|}{ Nutrients (calculated analysis) } \\
\hline Metabolizable energy (kcal/kg) & 2850 & 2868 & 3050 & 3107 & 3155 \\
\hline Protein (\%) & 30.34 & 26.16 & 25.42 & 23.37 & 22.92 \\
\hline Calcium (\%) & 1.36 & 1.27 & 1.26 & 1.23 & 1.03 \\
\hline Phosphorus (\%) & 0.76 & 0.68 & 0.68 & 0.65 & 0.53 \\
\hline Lysine (\%) & 1.681 & 1.44 & 1.39 & 1.27 & 1.17 \\
\hline Methionine (\%) & 0.738 & 0.684 & 0.702 & 0.669 & 0.651 \\
\hline
\end{tabular}


The experimental period lasted 15 weeks. The diets (Table 1) were prepared monthly; the food was granulated and mixed with a mixer with a $250 \mathrm{~kg}$ capacity. The diets were formulated using $\mathrm{ZMix} \mathrm{iT}^{\circledR}$ software (version 3.1, Zootech E.I.R.L., Lima, Peru). The experimental diets were formulated according to the requirements previously described by Rostagno et al. (2017) and divided according to the days of the experiment. The OEO was microencapsulated and supplemented in the feed.

\subsection{Measurements and sample collection} Feed intake $(\mathrm{kg})$ and body weight $(\mathrm{kg})$ were recorded weekly. Feed conversion was calculated weekly as consumed food (kg) divided by live weight $(\mathrm{kg})$ for each treatment. The average daily gain was calculated from the total increase in weight $(\mathrm{kg})$ divided by the total days of the experimental period. At the end of the experimental period, thigh meat and blood samples were taken from each group for oxidative stability testing using thiobarbituric acid reactive substances (TBARS) and cholesterol and triglyceride analyses, respectively.

\subsection{Oxidative stability}

Oxidative stability was measured as described by Maraschiello, et al. (1999) with slight modifications. Briefly, $0.5 \mathrm{~g}$ of thigh meat was weighed and homogenized in $5 \mathrm{~mL}$ of deionized water, then vortexed for $1 \mathrm{~min}$. Next, $2.5 \mathrm{~mL}$ of cold $25 \%$ (w/v) trichloroacetic acid (TBA) was added to the homogenate, followed by gentle stirring at 4 ${ }^{\circ} \mathrm{C}$ for $15 \mathrm{~min}$ and centrifugation for $15 \mathrm{~min}$ at $13000 \times \mathrm{g}$ and $4^{\circ} \mathrm{C}$. A $3.5 \mathrm{~mL}$ aliquot of the supernatant was taken and transferred to a test tube, $1.5 \mathrm{~mL}$ of $0.6 \%(\mathrm{w} / \mathrm{v})$ aqueous 2TBA added, and tubes incubated at $70^{\circ} \mathrm{C}$ for $30 \mathrm{~min}$. Then, the tubes were cooled in room temperature and the absorbance recorded at $532 \mathrm{~nm}$ against a blank consisting of 2.5 $\mathrm{mL}$ of deionized water, $1 \mathrm{~mL}$ of $25 \%$ aqueous TBA, and $1.5 \mathrm{~mL}$ of $0.6 \%$ TBA. The calibration curve was performed using the external standard method with a 1, 1, 3, 3tetraethoxypropane concentration series.

\subsection{Lipid parameters}

On the final day of the experiment (day 105) between 08:00 and 12:00, blood samples taken from the wing vein in tubes without additives. These samples were transported to the Laboratorio de Farmacología of the Facultad de Farmacia y Bioquímica of the Universidad Nacional de Trujillo, where they were centrifuged at $3000 \mathrm{rpm}$ for $10 \mathrm{~min}$ and the serum transferred to new Eppendorf tubes and stored at $-80{ }^{\circ} \mathrm{C}$. Besides, thigh meat samples from all birds were subsequently obtained and stored in Eppendorf tubes until analysis (up to 3 months).

\subsubsection{Total cholesterol determination}

Serum cholesterol levels were determined by the cholesterol esterase-oxidaseperoxidase enzymatic method using a commercial kit (Química Clínica Aplicada S.A., España). The results were expressed in $\mathrm{mg} / \mathrm{dL}$.

\subsubsection{Triglyceride determination}

Serum triglyceride levels were determined by the glycerol phosphate oxidase method using a commercial kit (Química Clínica Aplicada S.A., España). The results were expressed in $\mathrm{mg} / \mathrm{dL}$.

\subsection{Statistical analysis}

The experiment was designed with a completely randomized design. One-way analysis of variance (ANOVA) with Tukey post-test was used to determine productive parameters, oxidative stability, cholesterol, and triglycerides. A $p \leq 0.05$ was considered statistically significant. Values are expressed as the mean \pm standard error of the mean (SEM), and all statistical analyses were performed using GraphPad Prism software (San Diego, CA, USA).

\section{Results and discussion}

\subsection{Turkey performance}

Nutritional supplementation with oregano and its extracts have antioxidant, growthstimulating, antimicrobial, and immunostimulant properties in poultry. While the antioxidant benefits of bioactive components of oregano have been previously shown to protect the quality of poultry meat and its derivatives (Alagawany et al., 2018), most of these investigations were carried out in broilers. Therefore, the present study investigated the effect of dietary OEO supplementation on the productive parameters, oxidative stability, and lipid profiles of male turkeys.

Supplementation with OEO significantly increased $(p<0.001)$ the bodyweight of turkeys (OEO100: $11.42 \pm 0.33 \mathrm{~kg}$; OEO200: $11.94 \pm 0.27 \mathrm{~kg})$ compared to the control group $(9.7 \pm 0.22 \mathrm{~kg}$; Figure $1 \mathrm{~A})$. Likewise, the bodyweight of L\&S group turkeys was also significantly increased $(10.8 \pm 0.37 \mathrm{~kg}$, $p<0.001)$. However, the L\&S group was significantly overcome $(p<0.01)$ by the OEO200 group. Following our research, Chang-Song et al. (2017) observed that oregano powder significantly improved the bodyweight of broiler chickens compared to control, although it failed to overcome virginiamycin treatment. This also suggests 
that supplementation with OEO is more effective than oregano powder. Furthermore, treatment with a higher concentration of OEO $(200 \mathrm{mg} / \mathrm{kg})$ achieved the greatest body weight, consistent with research by Galal et al. (2016). This effect has been shown to plateau from 300 to $600 \mathrm{mg} / \mathrm{kg}$ OEO by Peng et al. (2016), and Mohiti-Asli and Ghanaatparast-Rashti (2017) showed the beneficial effects of 300 ppm OEO supplementation on weight exceeded that of 500 ppm OEO and control groups.

Interestingly, feed intake was significantly reduced in the OEO200 group $(21.34 \pm 0.4$ $\mathrm{kg})$ compared to control (23 $\pm 0.26 \mathrm{~kg}, \mathrm{p}<$ 0.001; Figure 1B), but not in OE0100 or L\&S birds. Although aromatic herbs and essential oils can improve taste and palatability, thereby increasing consumption (Skoufos et al., 2016), the opposite was found in the current and previous studies. Peng et al. (2016) and Mohiti-Asli and Ghanaatparast-Rashti (2017) have also shown that as the concentration of dietary OEO increases, consumption decreases. On the other hand, other investigations did not

A
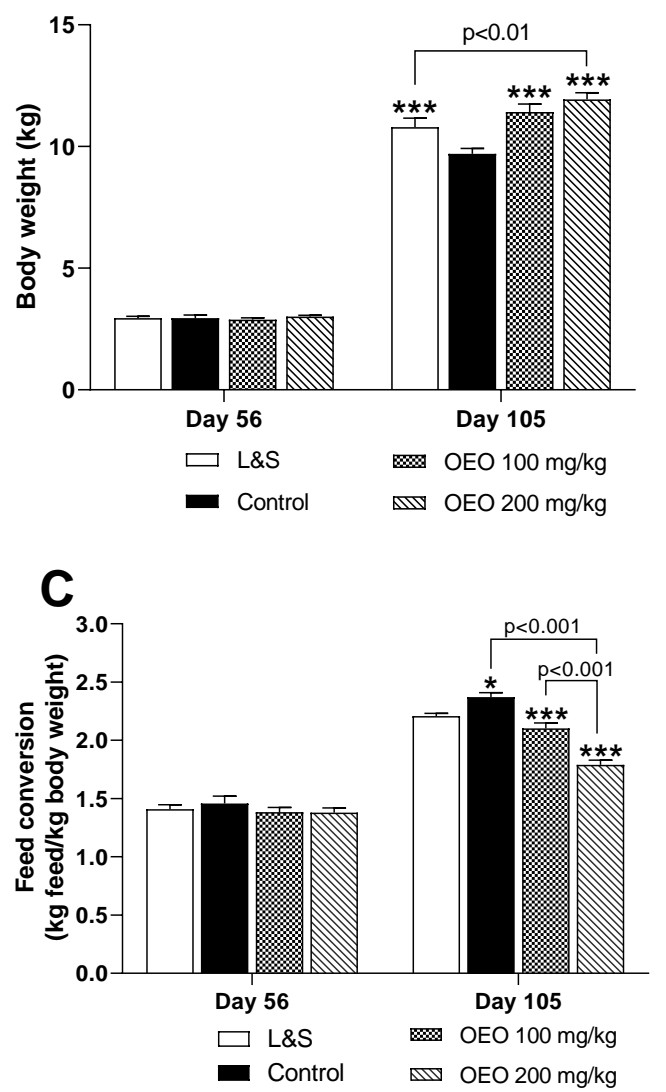

show this same effect of the OEO in quails and chickens (Badiri and Saber, 2016; Galal et al., 2016).

Like intake, feed conversion significantly decreased $(p<0.001)$ with increasing OEO concentration (OEO100: $2.1 \pm 0.05$; OEO200: $1.79 \pm 0.04)$ compared to control $(2.37 \pm 0.04$; Figure $1 \mathrm{C})$. The reduction with OEO200 was even more significant ( $p<$ $0.001)$ than the L\&S group $(2.21 \pm 0.02)$. Carvacrol and thymol, active components of OEO, are known to improve the rate of food conversion via inactivation of insulin in the liver (Lee et al., 2003a). Besides, The OEO has been shown to increase the height of ileal villi, reduce crypt depth, increase lactic acid bacteria, and reduce coliform populations in the ileum and cecum (Skoufos et al., 2016; Peng et al., 2016). Nonetheless, despite this evidence, many studies have reported that OEO does not exhibit a statistically significant positive effect in chickens and quails (Badiri and Saber, 2016; Galal et al., 2016; Skoufos et al., 2016; Peng et al., 2016; Mohiti-Asli and GhanaatparastRashti, 2017).
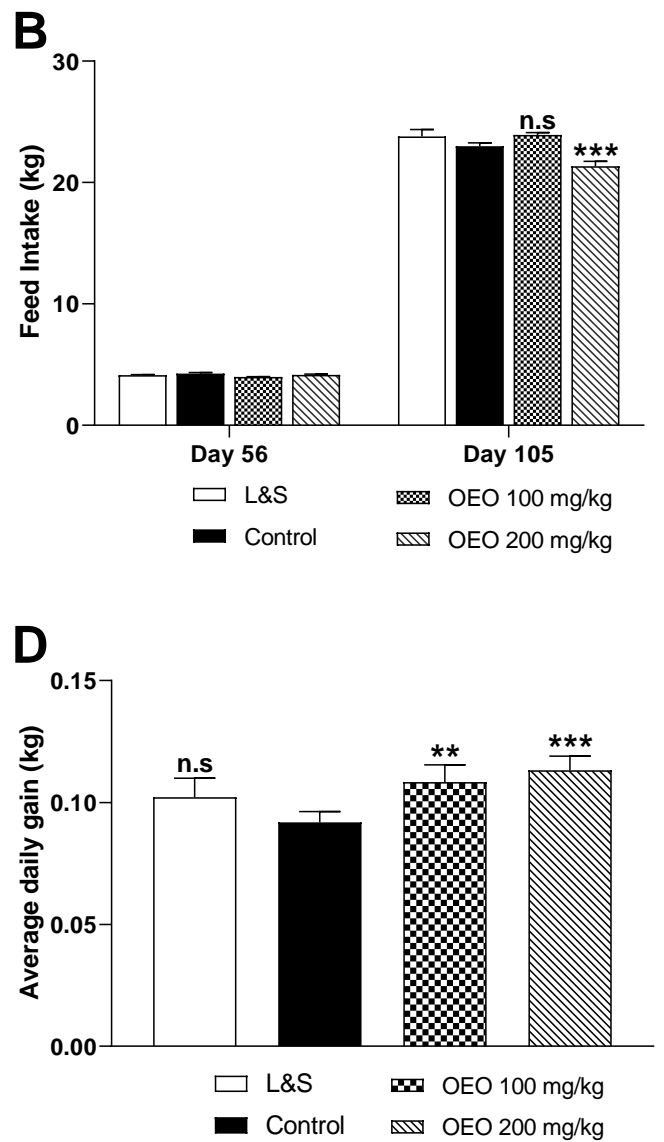

Figure 1. Effect of oregano essential oil (OEO) on body weight (A), feed intake (B), feed conversion (C), and average daily weight gain (D) of turkeys. ${ }^{*} p<0.05,{ }^{* *} p<0.01,{ }^{* *} p<0.001$ versus control. L\&S, $300 \mathrm{mg} / \mathrm{kg}$ lincomycin and spectinomycin; n.s., not significant. 
Average daily weight gain also improved significantly with OEO supplementation (OEO100: $0.108 \pm 0.003 \mathrm{~kg}, p<0.01$; OEO200: $0.113 \pm 0.006, p<0.001)$ compared to control $(0.09 \pm 0.002 \mathrm{~kg}$; Figure 1D), while the L\&S group gains did not significantly differ. These results are consistent with those of Peng et al. (2016) showing oregano powder improves average daily gain versus control. In contrast, Chang-Song et al. (2017) reported that average daily gains with oregano powder did not exceed that with antibiotic treatment. This suggests that OEO is more effective than oregano powder concerning weight gain.

\subsection{Oxidative stability}

Oxidative processes have been the focus of animal and meat scientists for decades due to the negative impact of these reactions on animal growth, yield, and food quality (Estévez, 2015). Poultry meat is particularly susceptible to oxidation mainly due to the high degree of unsaturated fatty acids as well as the presence of catalysts and molecular oxygen (Min and Ahn, 2005). Also, Salih et al. (1989) reported that turkey thigh meat was more susceptible to oxidation than turkey breast meat.

The present study found that supplementation with OEO and L\&S significantly reduced ( $p<0.001)$ MDA levels in turkey thigh meat (OEO100: $0.65 \pm 0.01 \mathrm{nmol} / \mathrm{g}$; OEO200: $0.96 \pm 0.01 \mathrm{nmol} / \mathrm{g}$; L\&S: $1.17 \pm$ $0.01 \mathrm{nmol} / \mathrm{g})$ with respect to control (1.28 \pm $0.04 \mathrm{nmol} / \mathrm{g}$; Figure 2). Both OEO concentrations also had significantly lower MDA levels than the L\&S group $(p<0.001)$. Also, OEO100 had the greatest effect on MDA levels versus OEO200 $(p<0.001)$. The presence of thymol and carvacrol explain the in vivo antioxidant effect of oregano essential oil (Yanishlieva et al., 2006). Thymol has been shown to increase the activity of endogenous antioxidant enzymes, such as superoxide dismutase, catalase, glutathione peroxidase, and glutathione- $S$ transferase, as well as the level of other nonenzymatic antioxidants, such as vitamin $C$, vitamin E, and reduced glutathione (Salehi et al., 2018). Likewise, thymol and carvacrol supplementation have been shown to increase antioxidant status and decrease MDA levels in broilers (Zidan et al., 2016; Hashemipour et al., 2013).

A previous study by Florou-Paneri et al. (2005) concluded that supplementation with $100 \mathrm{mg} / \mathrm{kg}$ OEO reduces MDA levels similar to $200 \mathrm{mg} / \mathrm{kg}$ OEO in both breast and thigh meat of turkeys. In the same way, the 100 $\mathrm{mg} / \mathrm{kg}$ OEO seems to reduce MDA levels in chicken tissues (Botsoglou et al., 2002). In contrast, another study showed that 100 $\mathrm{mg} / \mathrm{kg}$ OEO is not as effective in delaying lipid peroxidation in turkey meat compared to $200 \mathrm{mg} / \mathrm{kg}$ OEO (Botsoglou et al., 2003a; Botsoglou et al., 2003b). Similarly, Papageorgiou et al. (2003) and Govaris et al. (2004) reported that dietary supplementation with $200 \mathrm{mg} / \mathrm{kg}$ OEO exhibits great antioxidant activity in turkey meat. The disagreement in results could be attributed to the storage time (3 months) of turkey meat samples as longer storage times lead to greater denaturation and oxidation of proteins (Chan et al., 2011). Moreover, freezing damages the ultra-structure of meat and concentrates solutes (e.g., lipids and proteins), which in turn leads to a decrease in $\mathrm{pH}$ and alteration of biochemical reactions that occur at the cellular level and influence the physical quality of the meat (Leygonie et al., 2012). Furthermore, the differences in the methodology applied to measure the degree of lipid oxidation may have influenced the MDA levels (Botsoglou et al., 2003).

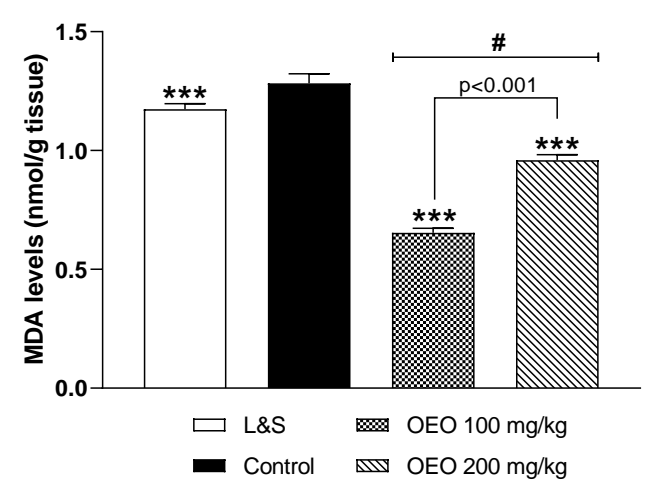

Figure 2. Level of malondialdehyde (MDA) in thigh muscle of turkeys. ${ }^{* * *} p<0.001$ versus control; $\# p<0.001$ versus L\&S. OEO, oregano essential oil; L\&S, $300 \mathrm{mg} / \mathrm{kg}$ lincomycin and spectinomycin.

\subsection{Lipid parameters}

No significant differences $(p>0.05)$ were found in serum cholesterol levels (Figure $3 A)$ between the treatment groups. These results are consistent with those reported by Bampidis et al. (2005) when studying the effect of OEO supplementation on female turkeys. Similarly, administration of 100 and $200 \mathrm{mg} / \mathrm{kg}$ thymol and $200 \mathrm{mg} / \mathrm{kg}$ carvacrol to the diet of female broilers revealed no differences in plasma cholesterol versus control birds (Lee et al., 2003a).

On the other hand, the average triglyceride levels in the OEO200 group $(66.67 \pm 1.93$ $\mathrm{mg} / \mathrm{dL})$ were significantly lower $(p<0.05)$ than those in the control group $(100 \pm 3.47$ $\mathrm{mg} / \mathrm{dL}$; Figure 2B). 
A

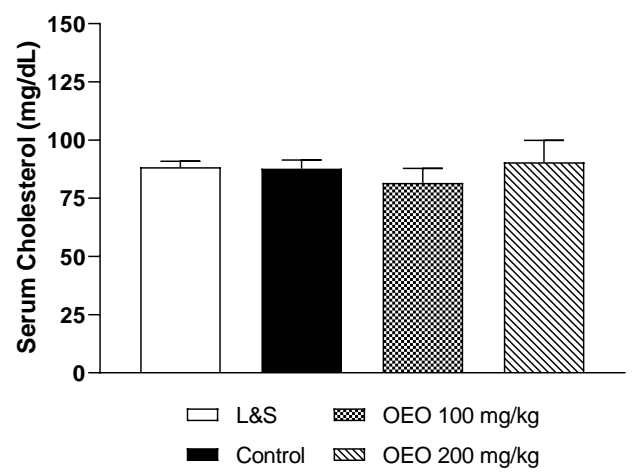

B

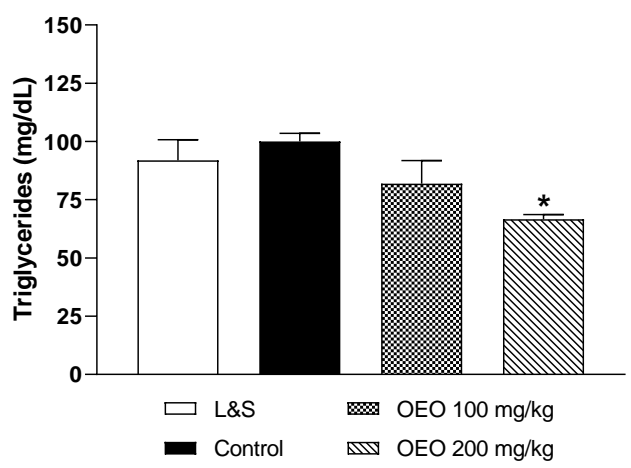

Figure 3. Effect of oregano essential oil (OEO) on serum cholesterol (A) and triglycerides (B) in turkeys. * $p<0.05$ versus control. L\&S, $300 \mathrm{mg} / \mathrm{kg}$ lincomycin and spectinomycin.

One study reported that dietary carvacrol and thymol do not have hypocholesterolemic activity. However, carvacrol, but not thymol, can reduce plasma triglyceride concentrations of broilers. This effect is caused mainly by de novo lipogenesis than by cholesterol biosynthesis (Lee et al., 2003b). Another study showed that carvacrol could inhibit visceral adipogenesis probably by suppressing morphogenic protein-mediated signaling, type 1 fibroblast growth factor, and galanin (Cho et al., 2012).

\section{Conclusions}

The present study demonstrated that dietary OEO supplementation improves the productive performance of turkeys. Therefore, it has the potential to act as a growth promoter, even surpassing antibiotics. Furthermore, OEO has an antioxidant effect on turkey meat and reduces triglycerides, not only improving the production capacity of the bird, but also the quality of the meat.

\section{ORCID}

L. Caceda-Gallardo iD https://orcid.org/0000-0002-9778-2621

G. Mendoza-Ordoñez (D) https://orcid.org/0000-0003-3714-1811

B. Loyaga-Cortéz (D) https://orcid.org/0000-0002-7343-0189

R. Ybañez-Julca iD https://orcid.org/0000-0003-0011-7957

D. Gonzales-Nonato iD https://orcid.org/0000-0001-5846-9563

D. Asunción-Alvarez (iD https://orcid.org/0000-0001-7498-2121

\section{References}

Adeyemi, K.D.; Olorunsanya, O.A. 2012. Comparative analysis of phenolic composition and antioxidant effect of four Cowpea (Vignna unguiculata) varieties on broiler meat. Iranian Journal of Applied Animal Science 2(4): 343-349.

Alagawany, M.; Abd El-Hack, M.E.; Farag, M.R.; et al. 2018. The usefulness of oregano and its derivatives in poultry nutrition. World's Poultry Science Journal 74(3): 463-474.

Ardoino, S.M.; Toso, R.E.; Toribio M.S.; et al. 2017 Antimicrobianos como promotores de crecimiento (AGP) en alimentos balanceados para aves: uso, resistencia bacteriana, nuevas alternativas $y$ opciones de reemplazo. Ciencia Veterinaria 19(1): 50-66.

Badiri, R.; Saber, S.N. 2016. Effects of dietary oregano essential oil on growth performance, carcass parameters and some blood parameters in Japanese male quail. International Journal of Pure \& Applied Bioscience 4(5): 17-22.

Bampidis, V.A.; Christodoulou, V.; Florou-Paneri, P.; et al. 2005. Effect of dietary dried oregano leaves on growth performance, carcase characteristics and serum cholesterol of female early maturing turkeys. British Poultry Science 46(5): 595-601.

Botsoglou, N.A.; Grigoropoulou, S.H.; Botsoglou, E.; et al. 2003a. The effects of dietary oregano essential oil and $\alpha$-tocopheryl acetate on lipid oxidation in raw and cooked turkey during refrigerated storage. Meat Science 65(3): 1193-1200.

Botsoglou, N.A.; Govaris, A.; Botsoglou, E.N.; et al. $2003 \mathrm{~b}$. Antioxidant activity of dietary oregano essential oil and $\alpha$-tocopheryl acetate supplementation in long-term frozen stored turkey meat. Journal of Agricultural and Food Chemistry 51(10): 2930-2936.

Botsoglou, N.A.; Florou-Paneri, P.; Christaki, E.; et al. 2002. Effect of dietary oregano essential oil on performance of chickens and on iron-induced lipid oxidation of breast, thigh and abdominal fat tissues. British Poultry Science 43(2): 223-230.

Chan, J.T.Y.; Omana, D.A.; Betti, M. 2011. Effect of ultimate $\mathrm{pH}$ and freezing on the biochemical properties of proteins in turkey breast meat. Food Chemistry 127(1): 109-117.

Chang-Song, R.; Xian-Ren, J.; Myong-Ho, K.; et al. 2017. Effects of dietary oregano powder supplementation on the growth performance, antioxidant status and meat quality of broiler chicks. Italian Journal of Animal Science 16(2): 246-252.

Cho, S.; Choi, Y.; Park, S.; et al. 2012. Carvacrol prevents diet-induced obesity by modulating gene expressions involved in adipogenesis and inflammation in mice fed with high-fat diet. The Journal of Nutritional Biochemistry 23(2): 192-201.

Domínguez, R.; Pateiro, M.; Gagaoua, M.; et al. 2019. A Comprehensive Review on Lipid Oxidation in Meat and Meat Products. Antioxidants (Basel) 8(10): 429.

Estévez, M. 2015. Oxidative damage to poultry: from farm to fork. Poultry Science 94(6): 1368-1378.

Félix, R.; Valentão, P.; Andrade, P.; et al. 2020. Evaluating the In Vitro Potential of Natural Extracts to Protect Lipids from Oxidative Damage. Antioxidants (Basel) 9(3): 231.

Florou-Paneri, P.; Palatos, G.; Govaris, A.; et al. 2005. Oregano herb versus oregano essential oil as feed supplements to increase the oxidative stability of turkey meat. International Journal of Poultry Science 4(11): 866-871. 
Galal, A.; El-Araby, I.; Hassanin, O.; et al. 2016. Positive impact of oregano essential oil on growth performance, humoral immune responses and chicken interferon alpha signaling pathway in broilers. Advances in Animal and Veterinary Sciences 4: 57-65.

Gatica-Eguiguren, M.A.; Rojas, H. 2018. Gestión sanitaria y resistencia a los antimicrobianos en animales de producción. Revista Peruana de Medicina Experimental y Salud Publica 35(1): 118-25.

Govaris, A.; Botsoglou, N.; Papageorgiou, G.; et al. 2004. Dietary versus post-mortem use of oregano oil and/or $\alpha$-tocopherol in turkeys to inhibit development of lipid oxidation in meat during refrigerated storage. International Journal of Food Sciences and Nutrition 55(2): 115-123.

Hashemipour, H.; Kermanshahi, H.; Golian, A.; et al. 2013. Effect of thymol and carvacrol feed supplementation on performance, antioxidant enzyme activities, fatty acid composition, digestive enzyme activities, and immune response in broiler chickens. Poultry Science 92(8): 2059-2069.

Hcini, E.; Ben Slima, A.; Kallel, I.; et al. 2018. Does supplemental zeolite (clinoptilolite) affect growth performance, meat texture, oxidative stress and production of polyunsaturated fatty acid of Turkey poults? Lipids in health and disease 17(1): 177.

Kiarie, E.; Walsh, M.C.; Nyachoti. C.M. 2016. Performance, digestive function, and mucosal responses to selected feed additives for pigs. Journal of Animal Science 94: 169-180.

Lee, K.W.; Everts, H.; Kappert, H.J.; et al. 2003a. Effects of dietary essential oil Components on growth performance, digestive enzymes and lipid metabolism in female broiler chickens. British Poultry Science 44: 450-457.

Lee, K.W.; Everts, H.; Kappert, H.J.; et al. 2003b. Dietary carvacrol lowers body weight gain but improves feed conversion in female broiler chickens. Journal of Applied Poultry Research 12: 394-399.

Leygonie, C.; Britz, T.J.; Hoffman, L.C. 2012. Impact of freezing and thawing on the quality of meat: Review. Meat Science 91(2): 93-98.

Łuczaj, W.; Gęgotek, A.; Skrzydlewska, E. 2017. Antioxidants and HNE in redox homeostasis. Free Radical Biology and Medicine 111: 87-101.

Maraschiello, C.; Sarraga, C.; García, J. 1999. Glutathione peroxidase activity, TBARS, and $\alpha-$ Tocopherol in meat from chickens fed different diets. Journal of Agricultural Food and Chemistry 47: 867 872.

Min, B.; Ahn, D.U. 2005. Mechanism of lipid peroxidation in meat and meat products - a review. Food Science and Biotechnology 14(1): 152-163.

Mohiti-Asli, M.; Ghanaatparast-Rashti, M. 2017. Comparison of the effect of two phytogenic compounds on growth performance and immune response of broilers. Journal of Applied Animal Research 45(1): 603-608.

Papageorgiou, G.; Botsoglou, N.; Govaris, A.; et al. 2003. Effect of dietary oregano oil and alphatocopheryl acetate supplementation on iron-induced lipid oxidation of turkey breast, thigh, liver and heart tissues. Journal of Animal Physiology and Animal Nutrition 87(9-10): 324-335.

Peng, Q.Y.; Li, J.D.; Li, Z.; et al. 2016. Effects of dietary supplementation with oregano essential oil on growth performance, carcass traits and jejunal morphology in broiler chickens. Animal Feed Science and Technology 214: 148-153.

Perez, D.M.; Tatiyaborworntham, N.; Sifri, M.; et al. 2019. Hemolysis, tocopherol, and lipid oxidation in erythrocytes and muscle tissue in chickens, ducks, and turkeys. Poultry Science 98(1): 456-463.

Rodriguez-Garcia, I.; Silva-Espinoza, B.A.; OrtegaRamirez, L.A.; et al. 2016. Oregano essential oil as an antimicrobial and antioxidant additive in food products. Critical Reviews in Food Science and Nutrition 56(10): 1717-1727.

Rostagno, H.; Teixeira, L.; Donzele, J.; et al. 2017. Tablas brasileñas para aves y cerdos. 4ta Edición. Universidad Federal de Viçosa. Viçosa, Brasil. 488 pp.

Salehi, B.; Mishra, A.P.; Shukla, I.; et al. 2018. Thymol, thyme, and other plant sources: Health and potential uses. Phytotherapy Research 32(9): 1688-1706.

Salih, A.M.; Price, J.F.; Simth, D.M.; et al. 1989. Lipid peroxidation in turkey meat as influenced by salt metal cations and antioxidants. Journal of Food Quality 12: 71-83

Skoufos, I.; Giannenas, I.; Tontis, D.; et al. 2016. Effects of oregano essential oil and attapulgite on growth performance, intestinal microbiota and morphometry in broilers. South African Journal of Animal Science 46(1): 77-88.

Stevanović, Z.D.; Bošnjak-Neumüller, J.; Pajić-Lijaković, I.; et al. 2018. Essential Oils as Feed Additives-Future Perspectives. Molecules 23(7): 1717

Vaitukaityte, R.; Januškevičiene, G.; Gruzauskas, R.; et al. 2013. Malondialdehyde levels in fresh and frozen turkey meat. Veterinarija ir Zootechnika 62: 85-91.

Yanishlieva, N.V.; Marinova, E.; Pokorny, J. 2006. Natural antioxidants from herbs and spices. European Journal of Lipid Science and Technology 108: 776793.

Xiong, W.; Sun, Y.; Zeng, Z. 2018. Antimicrobial use and antimicrobial resistance in food animals. Environmental Science and Pollution Research 25(19): 18377-18384

Zidan, D.E.; Kahilo, K.A.; El-Far, A.; et al. 2016. Ginger (Zingiber officinale) and thymol dietary supplementation improve the growth performance, immunity and antioxidant status in broilers. Global Veterinaria 16(6): 530-538. 